\author{
Łukasz Trembaczowski \\ Uniwersytet Śląski w Katowicach \\ (D) https://orcid.org/0000-0002-8914-3811
}

\title{
Reprodukcja klas posiadających a przekształcenia rynku
}

\begin{abstract}
The article is devoted to the problem of succession in family business in the perspective of class positions' reproduction. The analysis of succession is carried out with reference to Pierre Bourdieu's theory, particularly in relation to reconstruction entrepreneurs' class position within gradationally-relational model of social structure, description of economic field transformation and role played by entrepreneurs in that process, analysis of modal trajectories of entering the economic field and to strategies and forms of capitals reconversion. Transfer of capitals was entangled within model of transmission of knowledge, power and ownership in family enterprises. Succession next to starting own enterprise must be seen as one of dominant strategies for social position reproduction within a possessing class fraction. Those two ideal-type strategies can be mixed in practice of position reproduction and lead to hybridized forms of family business and new enterprise. Class position reproduction however, can lead also outside possessing class fraction to those richer in cultural rather than economic capital. Analysis of succession cannot therefore be limited to family business only but must be considered with reference to wider context of reproduction of social structure.
\end{abstract}

Key words: succession, family business, class position reproduction, economic field

Dotychczas problem sukcesji w firmach rodzinnych był w rozważaniach socjologów w Polsce właściwie nieobecny. Rodzima literatura przedmiotu jest stosunkowo nowa i uboga, a pojawiające się tytuły mają głównie charakter poradnikowy (Adamska et al., 2014; Lewand ow ska, 2015), strategiczno-biznesowy (Budziak, 2012; 2014), czy też koncentrują się na wybranych rozwiązaniach prawnych (Lewandowska, Lipiec, 2015). Jedyne studium badawcze poświęcone problematyce sukcesji uwzględniające perspektywę socjologiczną odwołuje się do teorii wymiany (Safin, Pluta, Pabjan, 2014). Wybrane podejście teoretyczne może i dobrze wpisuje się w utylitarną charakterystykę prowadzonych w Polsce 
badań nad sukcesją, nie pozwala jednak na umieszczenie procesów sukcesyjnych w szerszej perspektywie socjologicznej. Taką zaś perspektywę przyjmuje ogólniejszy proces reprodukcji klas posiadających, których istotną frakcję stanowią właściciele przedsiębiorstw rodzinnych. Tym samym chciałbym niejako usprawiedliwić tytuł artykułu, który w pierwszej chwili mógł się czytelnikowi jawić jako znacznie szerszy niż opisywane w nim zjawisko.

Jednak perspektywa reprodukcji klasowej musi jeszcze zostać rozszerzona o przemiany, jakim podlegały w ciągu ostatnich 25 lat rodziny w Polsce i na świecie, czyli o zjawiska ,kryzysu rodziny”, czy też alternatywnych modeli rodzinnych (Szlendak, 2010). Wszelkie bowiem przekształcenia naszego rozumienia rodziny przenoszą się na pojmowanie zakresu pojęcia „firma rodzinna”, a przez to także na zdefiniowanie zasięgu grup sukcesorów, nestorów oraz stosunków między członkami tych grup. Ponadto ze względu na długotrwałość procesu, jakim jest sukcesja, oraz zróżnicowanie zaangażowanych w ten proces stron (nie tylko rodzina, ale też pracownicy), potrzebne jest podejście procesualne i relacyjne. Uważam, że odpowiedni potencjał analityczno-eksplanacyjny znaleźć można w teorii Pierre’a Bourdieu, na której chciałbym oprzeć swoje rozważania.

\section{Reprodukcja klas w kontekście teorii Pierre’a Bourdieu}

Dorobek teoretyczny Pierre'a Bourdieu jest w Polsce dobrze rozpoznany i jego szczegółowe omawianie wydaje się zbędne, gdyż zostało to wykonane lepiej przez innych autorów (Jacyno, 1997). Dlatego też chciałbym ograniczyć się jedynie do przywołania kilku rozróżnień, które będą wykorzystywane w dalszej części tekstu.

Na koncepcję struktury społecznej Bourdieu można spojrzeć jak na próbę przekroczenia zaproponowanego przez Stanisława Ossowskiego podziału na gradacyjne i relacyjne ujęcie klas (1968). Podejście gradacyjne ukazuje strukturę społeczną jako zhierarchizowaną ze względu na posiadane zasoby wiedzy, władzy i bogactwa, natomiast podejście relacyjne odwołuje się do dychotomicznego i antagonistycznego ujęcia struktury społecznej, w którym zasoby te są biegunowo skumulowane przez jedną z klas, podczas gdy druga jest ich pozbawiona. Choć oba te ujęcia odwołują się do różnych tradycji (odpowiednio weberowskiej i marksowskiej), to sam czynnik różnicujący położenia klasowe jest mniej istotny od enumeratywnego bądź asocjatywnego jego traktowania. Na przykład postrzeganie sytuacji ekonomicznej na sposób Marksowski (własność środków produkcji) jako cechy asocjatywnej - prowadzi do relacyjnego postrzegania stosunków klasowych (posiadający/nieposiadający). Natomiast postrzeganie owej sytuacji ekonomicznej w ujęciu Weberowskim (jako szans związanych z posiadaniem i zarobkowaniem) - jako cechy asocjatywnej (szanse te przysługują wszystkim choć w różnym stopniu) — prowadzi do gradacyjnego ujęcia tychże stosunków. 
W podejściu Pierre’a Bourdieu te dwa ujęcia zostały zintegrowane w jeden spójny koncept teoretyczny.

Gradacyjny aspekt struktury społecznej w jego koncepcji jest łatwiejszy do wykazania choćby ze względu na przyjęty podział na klasy wyższe, średnie i popularne. Przynależność klasowa zaś wyznaczana jest poziomem kapitałów (ekonomicznego, społecznego i kulturowego), którymi dysponuje jednostka. Rozwarstwienie klasowe spowodowane ogólnym poziomem wyposażenia w kapitały nie może być mylone z homogenicznością wyodrębnionych klas. „Różnice w globalnej wielkości kapitału zawsze niemal zasłaniają [...] drugorzędne różnice, które wewnątrz każdej z klas określanych poprzez globalną wielkość jej kapitału wydzielają różne frakcje klasowe definiowane przez odmienne struktury dziedziczenia, to znaczy przez inne formy rozkładu ich globalnego kapitału między rodzaje kapitału" (Bourdieu, 2005, s. 150). Przedsiębiorcy właściciele firm rodzinnych przynależą więc do tych frakcji klas wyższych i średnich, których reprodukcja uzależniona jest od przekazania kapitału ekonomicznego. Do ogólnej struktury dziedziczonych w firmach rodzinnych kapitałów przyjdzie jeszcze powrócić w dalszej części tekstu, tutaj jednak warto podkreślić enumeratywny charakter rozumienia koncepcji kapitału, który w każdej z klas i frakcji klasowych występuje w jakimś stopniu na podobieństwo Weberowskich szans rynkowych. To bowiem zasoby kapitałów, którymi dysponuje jednostka, będą jej umożliwiały (lub uniemożliwiały) podjęcie walki w danym polu (polu ekonomicznym w przypadku przedsiębiorców).

Nieco trudniej wskazać relacyjny charakter stosunków w strukturze społecznej, skoro odzwierciedla ona zhierarchizowaną dystrybucję kapitałów. Zdaniem Pierre'a Bourdieu, czynnikiem różnicującym klasy dychotomicznie jest dominacja, a czynnikiem nierozerwalnie związanym z dominacją jest kapitał symboliczny w swej nierozpoznanej, ale uznanej formie albo raczej uznanej, właśnie przez to, że nierozpoznanej. Kapitał symboliczny stanowi więc formę władzy zaprzeczonej, „jest tak dlatego, że dominacja działa tylko w formie elementarnej, czyli między osobami, nie może dokonywać się otwarcie i musi się ukrywać pod pozorami zaczarowanych relacji” (Bourdieu, 2008, s. 171). Dominujący muszą jednak przez swoje praktyki bezustannie odtwarzać warunki dominacji, gdyż odczarowanie nagich praktyk „,czystego zysku” uniemożliwiłoby ich uprawomocnienie, a w wyniku tego naturalizację przez zdominowanych. Jednak to odtwarzanie dominacji jest znacznie łatwiejsze w przypadku jej obiektywizacji w instytucjach, nie jest bowiem konieczne ciągłe interakcyjne odtwarzanie owej dominacji. Takie zinstytucjonalizowane, autonomiczne pola pozwalają więc oszczędzić wysiłków, które pochłonęłoby stałe zaangażowanie w bezpośrednią dominację. Dlatego też tak istotne dla szans reprodukcyjnych staje się wytwarzanie w obrębie struktury społecznej odpowiednich habitusów związanych z owymi polami, a w szczególności habitusów klasowych, które na zasadzie ukrycia władzy pozwalają na przypisanie prestiżu tym, którzy mają dominujące pozycje w polach. Tym samym, odnosząc te rozważania do struktury społecznej, podział na klasy dominujące, czyli wyższe, i zdominowane, czyli pozostałe, przyjmuje charakter asocjatywny, 
którego nie przejawiałaby prosta zasada akumulacji kapitałów obecna we wszystkich klasach ${ }^{1}$.

Tym, co łączy oba te ujęcia, jest tocząca się w klasach wyższych walka o wiodącą zasadę dominacji, czyli kontrolę nad zasadą hierarchizacji. Możliwość konwersji kapitałów oraz odwrotnie - symetryczna dystrybucja kapitałów w klasie dominującej prowadzą bowiem do ciągłej walki pomiędzy frakcjami owej klasy o uznanie jako podstawy hierarchizacji tego typu kapitału, którym dysponują w większym stopniu.

\section{Ewolucja pola produkcji ekonomicznej i geneza klas posiadających w Polsce}

Rozważaniom poświęconym reprodukcji klas posiadających (podobnie jak węziej zdefiniowanej sukcesji) towarzyszy implicytne założenie o pewnej świeżości, czy też raczej braku zasiedziałości tych klas w burżuazji. Innymi słowy, analizowane procesy sukcesyjne mają być pierwszą falą sukcesji w firmach powstałych w okresie boomu początku lat 90 . XX wieku. Od tego momentu upłynęło już 25 lat, co zwykle przyjmuje się jako miernik pokolenia. Tak więc na scenę wkraczać ma nowe pokolenie przedsiębiorców, którzy przejmują swoje firmy od rodziców — założycieli. Przede wszystkim konieczne jest rozważenie zasadności tego założenia, a także odniesienie do koncepcji habitusu — pola, które pozwala spojrzeć na przekształcenia struktury społecznej i wyłonienie się klas posiadających w bardziej złożony sposób.

Spojrzenie na odtwarzanie się stosunków kapitalistycznych i wyłonienie klasy przedsiębiorców po roku 1989 wpisuje się, jak zauważa Marta Bucholc, w narrację powrotu na tory rozwoju z okresu międzywojennego, z których zostaliśmy zepchnięci przez wojnę i okres PRL-u. Tym samym czasy dwudziestolecia międzywojennego to „ostatni historyczny okres, gdy drobni przedsiębiorcy zajmowali poczesne miejsce w społecznej wyobraźni. [...]. Przedsiębiorcy tego okresu to w naszej wyobraźni zbiorowej prawdziwi kapitaliści z etosem" (Bucholc, 2012, s. 14). Niezależnie od wykazanego przez Martę Bucholc onirycznego i życzeniowego charakteru owych wyobrażeń istotne jest poszatkowanie ciągłości rozwojowej na okresy II RP, zerwanej ciągłości w okresie drugiej wojny światowej oraz długiego okresu gospodarki centralnie sterowanej. Prowadzi to do postrzegania pola ekonomicznego i narodzin przedsiębiorstw prywatnych po roku 1989 jako creatio ex nihilo, powstania kapitalizmu bez kapitalistów (Eyal, Szelenyi, Townsley, 1998). Stawiając więc Tocqueville'owskie pytanie o to, co faktycznie zmieniła rewolucja, można spojrzeć na okres III RP jako właśnie narodziny

${ }^{1}$ Trzeba jednak zaznaczyć, że Bourdieu odcinał się od substancjalnego pojmowania klasy (typowego dla Marksa), określając klasy jako skonstruowane na papierze (Bourdieu, 1985). 
zupełnie nowego ładu — przygotowanego bądź nie w poprzednim ustroju — gdzie kapitalizm odradza się dzięki heroicznym wysiłkom nowej, odradzającej się klasy kapitalistów. Jeśli jednak, zamiast rozpoczynać od tzw. ustawy Wilczka jako genezy (proto)kapitalistycznych przedsiębiorstw, skupimy uwagę na tym, dlaczego w ogóle ustawy te stały się możliwe, to w połączeniu z koncepcją pola pozwoli postawić roboczą hipotezę o autonomizacji pola produkcji ekonomicznej wobec dominującego w systemie gospodarki centralnie sterowanej systemu politycznego. System polityczno-gospodarczy „realnego socjalizmu”, czy też „komunizmu”, opierał się bowiem na myśli marksistowsko-leninowskiej, w której stosunki ekonomiczne i klasowe zostały upolitycznione. Wraz z wprowadzeniem ustroju komunistycznego (co też nie odbyło się bez trudności i z całą pewnością nie od razu) sfera ekonomiczna czy inaczej pole produkcji ekonomicznej (przyjęcie perspektywy pola pozwala przekroczyć problemy definiowania rynku w okresie PRL oraz III RP) zostało podporządkowane sferze polityki i całkowicie przez nią zdominowane. Niemniej wraz z powracającymi cyklicznie kryzysami gospodarczymi i politycznymi przesileniami sfera ta zyskiwała coraz większą autonomię wobec pola politycznego. Ta częściowa autonomia stała się możliwa nie dzięki niedokończonej kolektywizacji rolnictwa (gdzie przetrwała indywidualna własność środków produkcji) czy prywatnej inicjatywie (która była funkcjonalnie niezbędnym, choć ideologicznie niepożądanym elementem tegoż systemu), ale właśnie dzięki walce o zasadę dominacji wewnątrz dominującej klasy, za jaką można uznać nomenklaturę partyjną (Domański, 2015, s. 90-93). Konflikt wewnątrz tej klasy wokół dominującej zasady dominacji doprowadził w końcu do wyłonienia się heterodoksji prymatu gospodarki nad polityką. Najlepszym wskaźnikiem owej sytuacji jest przesunięcie wagi ze stanowisk stricte politycznych na ekonomiczne w nomenklaturze, które z biegiem czasu stawały się bardziej pożądane (Gardawski, 2013, s. 57). Ta postępująca i systematyczna autonomizacja technokratów z zachowaniem, przynajmniej początkowo, ram polityczno-ustrojowych pozwoliła na krystalizowanie się nowej doksy. W tym kontekście ustawy Wilczka należy uznać po prostu za kolejny krok w jej ustanawianiu, logiczną konsekwencję niepowodzenia prób obrony komunistycznej ortodoksji. Choć zarysowane wyjaśnienie wymaga jeszcze uzupełnienia i rozbudowania, to pozwala na ukontekstowienie narodzin klas posiadających.

Spory wokół genezy tych klas można poddać metaanalizie, kiedy skupimy się na modalnych trajektoriach wejścia do klas posiadających. Pierwszą z trajektorii można zanalizować w kategoriach konwersji kapitału politycznego (typowego dla poprzedniego ustroju i podlegającego wraz z początkiem transformacji szybkiej inflacji) w kapitał ekonomiczny sensu stricto. Ta trajektoria wpisuje się w narrację „uwłaszczenia nomenklatury” (Staniszkis, 1990; Wasilewski, 1995). Pomijając dyskusję dotyczącą skali owego procesu, za istotne przyjmuje się zróżnicowanie zakresu owych konwersji. W przypadku średnich warstw nomenklatury

${ }^{2}$ Ustawa o wolności gospodarczej z 1988 roku.

${ }^{3}$ Spór wokół nazwy najbardziej odpowiedniej do opisania tego okresu wykracza poza ramy nakreślone tematem i tym samym został pominięty, choć nie zignorowany. 
technicznej dochodziło do przejęć części wyposażenia przedsiębiorstw państwowych (oraz najlepiej wykwalifikowanych pracowników) i budowania w oparciu o nie własnych nowych przedsiębiorstw. Juliusz Gardawski nazywa to przejęciem hardware'u przedsiębiorstw (Gardawski, 2013, s. 63).

Drugą znaczącą trajektorię stanowi konwersja kapitału kulturowego (zarówno wcielonego, jak i zinstytucjonalizowanego) w kapitał ekonomiczny. Można tutaj przywołać zarówno kwestie uwłaszczenia software'u przedsiębiorstw państwowych (know-how), czyli znajomości rynków zbytu, dostawców, kooperantów oraz procesów produkcji i zarządzania, na bazie których dawni pracownicy zakładów państwowych budowali własne firmy (Gardawski, 2013, s. 63), jak i tych przedsiębiorców, którzy posiadali odpowiedni kapitał kulturowy, jednak nie weszli w skład nomenklatury albo mieli zbyt niską pozycję, by móc dokonać uwłaszczenia (np. absolwenci technicznych kierunków uczelni wyższych nieznajdujący stanowisk odpowiadających ich aspiracjom) i postanowili wykorzystać wiedzę do budowy własnych przedsięwzięć.

Trzecim kanałem wejścia mogła być rekonfiguracja kapitału ekonomicznego zgromadzonego bądź w wyniku quasi-legalnych działań (np. wywożenia za granicę towarów na sprzedaż), bądź dzięki pracy za granicą (co umożliwiły spółki joint-venture). Owe skromne jak na warunki zachodnie zasoby nie pozwalały oczekiwać długoterminowych korzyści (np. oszczędności w walucie w dobie PRL), wobec czego ich inwestycja pozwalała na potencjalnie długofalowe zyski. W zależności od wielkości owych zasobów pozwalało to na założenie własnych przedsiębiorstw (np. importowych) bądź wprost na przejmowanie niedokończonych prywatyzacji. Ten drugi przypadek wpisuje się też w sygnalizowaną wcześniej trajektorię uwłaszczeń, które nie zawsze kończyły się powodzeniem ze względu na brak zdolności „starych" nowych managerów do zgromadzenia odpowiednio dużych zasobów finansowych, by dokończyć przejęcie całego przedsiębiorstwa. Tak rozpoczęte prywatyzacje mogły stać się łatwym sposobem na inwestycję zgromadzonego kapitału.

Pozostają jeszcze ścieżki wejścia z konieczności (choć i w przypadkach wcześniej omówionych mogło dochodzić do sytuacji braku alternatywy) tych byłych pracowników zakładów państwowych, którzy stracili pracę w okresie transformacji i podjęli się działalności gospodarczej, oraz członków Solidarności, którzy zostali zwolnieni z pracy jeszcze przed rokiem 1989 i nie mieli możliwości znalezienia zatrudnienia w zakładach państwowych. Wiele z tych inicjatyw podejmowanych z konieczności oparte było na bardzo prostych pomysłach i nie przetrwało próby czasu bądź dziś zasila kategorię, którą za Millsem można nazwać lumpenburżuazją (Mills, 1965, s. 95-103).

Podsumowując, poszczególni aktorzy lokujący się w polu produkcji ekonomicznej wnosili do przedsiębiorstwa przede wszystkim inne kapitały niż ekonomiczny. Nie zmienia to jednak faktu, że wraz z sukcesem heterodoksji prymatu gospodarki $i$ autonomizacją pola ekonomicznego wobec sfery politycznej (proces ten nie został zakończony, a w niektórych obszarach, jak np. energetyka, można dostrzec powolne odwracanie się ponownie w kierunku etatyzmu) przedsiębiorcy znaleźli się w sferze w dużej mierze rozregulowanej, pogrążonej w anomii. Owa bifurkacja systemu 
doprowadziła jednak do wykształcenia się dominującego w polu ekonomicznym typu kapitału. Problemem transformacji pozostała kwestia przekształcenia kapitału ekonomicznego w symboliczny, gdyż wielu przedstawicielom rodzących się klas posiadających prawa do posiadania odmawiano. Zgodnie z zasadą, że nie wystarczy posiadać, trzeba jeszcze móc posiadać, nie zawsze zyskiwali oni prestiż związany $\mathrm{z}$ osiągniętą pozycją $\mathrm{w}$ polu. Ma to jednak większy związek z walką o naczelną zasadę dominacji wewnątrz klas dominujących niż z walkami w samym polu ekonomicznym. Nie wnikając w to, czy inteligencji udało się utrzymać pozycję i uczynić z kapitału kulturowego najważniejszy z kapitałów (Zaryck i, 2009), istotne jest to, że wchodząc $\mathrm{w}$ pole produkcji ekonomicznej, przedsiębiorcy wyposażeni w różne habitusy (niekoniecznie dostosowane do pola, w którym podjęli grę) zaczęli zawierać sojusze, wymieniać ciosy i ustalać reguły gry, współtworząc i przekształcając owo pole. Ta założycielska generacja (na pytanie, w jakim stopniu zasadne jest to określenie, przyjdzie jeszcze odpowiedzieć) przyczyniła się do wykształcenia pola ekonomicznego rządzącego się swoimi regułami, w którym struktura kapitałów ulegała systematycznej przemianie. Zgodnie więc z wyłaniającą się logiką pola, kapitał ekonomiczny stał się najistotniejszy, a sukces osiągnęli ci gracze, którzy szybko i skutecznie dokonali konwersji swoich kapitałów w zasoby finansowe czy majątek przedsiębiorstw. Te przemiany przyczyniły się do wykształcania się habitusów wtórnych przedsiębiorców, którzy myślenie w kategoriach biznesowych przyjęli jako swoistą logikę pola. Nie tylko przedsiębiorcy wykształcili zatem czy raczej przekształcili pole produkcji ekonomicznej i zasady w nim obowiązujące, ale równocześnie ucząc się gry, nabyli habitusy dostosowane do pola i zinternalizowali sobie owe reguły. Istotnym czynnikiem jest kwestia konsumpcji, która wykracza nieco poza zakres zainteresowań naznaczony w tytule. Wypada jednak wspomnieć, że posiadanie dużych zasobów ekonomicznych niekoniecznie przekładało się na bezpośrednią konsumpcję, a wielu z tych przedsiębiorców, którzy zbyt wcześnie zaczęli konsumować zasoby, utraciło swoje pozycje i szanse w polu. Przez większość okresu transformacji przedsiębiorcy często i tak posiadali wystarczające zasoby do prowadzenia konsumpcji na wyższym poziomie niż pozostałe klasy, tak by zachować dystans ekonomiczny i jednocześnie nie wpływać negatywnie na swoje przedsiębiorstwa ${ }^{4}$.

Przyjęte założenie o pionierskim charakterze czy wręcz o pierwszej generacji przedsiębiorców wymaga konfrontacji z problemem prywatnej inicjatywy doby PRL-u. Jeśli bowiem postawić tezę, że mamy do czynienia z pierwszą falą sukcesji w klasie właścicieli, konieczne staje się odniesienie do tych przypadków, w których firmy istnieją już co najmniej w trzecim pokoleniu (najstarsza w Polsce firma rodzinna Ludwisarnia Felczyńskich działa już od sześciu pokoleń). Pominięcie wejścia do klasy przedsiębiorców wskutek sukcesji pozycji w firmach rodzinnych, które w poprzednim ustroju określano mianem prywatnej inicjatywy, może wydawać się sporym uchybieniem, jednak trzeba rozważyć losy tej warstwy w okresie

${ }^{4}$ Ułatwiały to także stosunkowo niskie zarobki innych warstw, w tym pracowników owych firm. 
transformacji. Wbrew pozorom grupa ta, pomimo sporego doświadczenia w prowadzeniu własnej działalności gospodarczej, nie była dobrze przygotowana do konkurencji. Istotnym paradoksem gospodarki centralnie sterowanej było bowiem to, że warstwa ,prywaciarzy” była ideologicznie niepożądana i traktowana jako schyłkowa. Jednak pomimo ponad czterech dekad funkcjonowania gospodarki centralnie sterowanej wcale nie zaniknęła, ale stanowiła kategorię najlepiej uposażoną ekonomicznie. Stan ten wynikał nie tylko z niedostatków poprzedniego ustroju, ale także z realnego braku konkurencji (firmy te działały często w drobnym rzemiośle, w ramach którego zainteresowanie państwa zaspokajaniem potrzeb ludności było niewielkie). Co więcej, przyzwyczajona do ostrożnej zaradności (Gardawski, 2013), nie potrafiła w pełni wykorzystać przemian ustrojowych i rozwinąć działalności gospodarczej na szerszą skalę. Dobra pozycja początkowa w połączeniu ze wzrostem dochodów dzięki uwolnieniu działalności na chłonnym rynku nie motywowała do wprowadzania istotnych zmian. Pojawienie się konkurencji, np. w postaci towarów eksportowych czy też nadwyżek towarów dotąd deficytowych, okazywało się dla tych firm trudnym wyzwaniem. Pomimo trudności część firm przetrwała okres transformacji i dziś również podlega sukcesji. Jeśli jednak porównać sytuację początkową i obecną, można postawić tezę o względnym niepowodzeniu owej warstwy. Z całą pewnością nie stała się ona ani zaczynem, ani rdzeniem rodzących się klas kapitalistycznych. W wielu wypadkach pozostaje nadal ograniczona do działalności w niewielkiej skali często bez potencjału sukcesyjnego. W przypadku tych firm, które jednak przetrwały i rozwinęły się po roku 1989, można postawić roboczą hipotezę o podobieństwie sytuacyjnym do firm nowo powstających (np. działalność w garażu lub warsztacie przylegającym do domu). Habitusy pierwotne takiej prywatnej inicjatywy podlegały podobnym przekształceniom jak pozostałych grup założycielskich, a być może nawet większym. Podobnie do innych aktorów w polu przedstawiciele prywatnej inicjatywy uczyli się nowych reguł od podstaw i podobnie do nich nabywali sprawności w grze rynkowej (lub przegrywali). Innymi słowy, przekształcenie niewielkiej garażowej firmy rzemieślniczej (będącej nieraz dodatkową działalnością) w średniej wielkości przedsiębiorstwo nie różni się istotnie od rozpoczęcia działalności na bazie fragmentów przedsiębiorstwa państwowego lub w oparciu o posiadaną wiedzę, w związku z czym kwestia rekonwersji kapitałów staje się podobna, gdyż struktura kapitałów podlegających dziedziczeniu dziś jest zasadniczo odmienna od sytuacji sukcesji w ramach prywatnej inicjatywy w dobie PRL.

\section{Struktura dziedziczenia w przedsiębiorstwach rodzinnych}

Sukcesja wpisana jest w samą istotę koncepcji firmy rodzinnej. W istocie trwanie ponad pokoleniami pojawia się w większości definicji biznesu rodzinnego (Safi in, 2007). Można spojrzeć na tę transgeneracyjność jak na cechę dystynktywną 
firm rodzinnych. Nie jest to tylko kwestia definicyjna, gdyż intencja zachowania majątku i kontroli nad przedsiębiorstwem w rękach rodziny znajduje odzwierciedlenie w podejmowanych decyzjach strategicznych. Choć w momencie zakładania przedsiębiorstwa mało kto myśli o nim od razu jako o firmie rodzinnej, to jednak wraz z upływem czasu właściciel musi zdecydować, jak zarządzać majątkiem firmy, a przy podejmowaniu tych decyzji uwzględniać długofalową perspektywę. Innymi słowy, wcześniej czy później każdy przedsiębiorca musi uwzględnić kwestię przekazania firmy bądź majątku. Dostępne rozwiązania można zasadniczo podzielić na trzy możliwe ścieżki: firma zostaje przekazana następcom z rodziny i pozostaje w ich zarządzie; firma zostaje przekazana sukcesorom, ale zarząd nad firmą wyjęty jest spod kontroli rodziny (która nie kieruje firmą aktywnie, ale wciąż ma wpływ - większy lub mniejszy — na zarządzanie) oraz firma zostaje sprzedana, a majątek rozdzielony pomiędzy sukcesorów. Oczywiście te typy mogą zostać zmultiplikowane w sytuacji pojawienia się wspólników czy udziałowców zewnętrznych. Tylko pierwszy z owych typów można bez zastrzeżeń nazwać sukcesją w firmie rodzinnej. Firma może też oczywiście zostać podzielona na mniejsze części przekazywane poszczególnym sukcesorom, co jednak wpisuje się w dużej mierze w kryterium sukcesji, zarówno bowiem zarząd, jak i własność pozostają $\mathrm{w}$ rękach rodziny. Przekazanie zarządu zewnętrznemu managementowi z zachowaniem własności jest nieco bardziej skomplikowaną sytuacją. To, czy mamy wtedy do czynienia $\mathrm{z}$ sukcesją $\mathrm{w}$ firmie rodzinnej, zależy w dużej mierze od sposobu definiowania firmy rodzinnej. Sytuacja ta staje się bardziej złożona wraz z upływem kolejnych pokoleń od momentu założenia firmy.

Typowy scenariusz rozwojowy obejmuje kolejne fazy. W pierwszej — firma jest własnością założyciela, który aktywnie nią kieruje i tworzy ją od podstaw. W drugim pokoleniu, po udanej sukcesji, firma przechodzi w ręce dzieci, jest więc kierowana przez rodzeństwo. W trzecim pokoleniu firma przechodzi w ręce wnucząt założyciela i jest kierowana przez kuzynostwo (Bu dziak, 2012). Z każdym kolejnym pokoleniem rośnie liczba potencjalnych sukcesorów, spadkobierców, beneficjentów majątku firmy, a jednocześnie zmniejsza się ich bezpośredni związek z firmą (trudno, by w kilkunasto- bądź kilkudziesięcioosobowej grupie kuzynostwa wszyscy znaleźli zatrudnienie w firmie, nie mówiąc o kierowaniu nią). Tym samym na pewnym etapie rozwoju konieczne staje się powołanie managementu profesjonalnego. Oczywiście taka sytuacja zakłada stały rozrost firmy i zwiększanie się jej dochodów oraz zdolność rodziny do ustalenia konkretnych warunków zarząadzania majątkiem rodzinnym. W wielu wypadkach nie udaje się utrzymać tak korzystnej sytuacji i dlatego właśnie wiele firm rodzinnych upada w trzecim pokoleniu.

Obserwowalna w ostatnich latach rosnąca fala sukcesji w firmach rodzinnych wpisuje się w sytuację sukcesji z pierwszego do drugiego pokolenia. Od początku transformacji minęło ponad 25 lat, co jest typową cezurą pokoleń, dlatego pojawienie się pewnej kumulacji procesów sukcesyjnych nie jest zaskakujące. Możemy więc mówić o bezprecedensowej wręcz sytuacji, gdyż rodzinom biznesowym brak zarówno doświadczenia, jak i przykładów, na których mogłyby się wzorować. Dla- 
tego też nie jest zaskakujący fakt zainteresowania praktyczną stroną tego procesu oraz konkretnymi przykładami udanych sukcesji.

Jeśli jednak szerzej spojrzeć na zjawisko sukcesji przez pryzmat zarysowanego kontekstu socjologicznego, nie sposób nie zauważyć, że każdy z trzech zarysowanych typów rekonfiguracji wpisuje się we wspólną kategorię dziedziczenia pozycji klasowych. Wynika to wprost ze struktury dziedziczenia, w której kapitał ekonomiczny jest kluczowy dla udanej reprodukcji pozycji klasowych. Jak reprodukcja tradycyjnie pojmowanej arystokracji wymagała udanego przekazania tytułu, majątku i rezydencji, tak reprodukcja pozycji przedsiębiorcy wymaga przekazania własności i zarządu w firmie. Jednakże pozostanie w gronie klas posiadających nie musi oznaczać koniecznie transferu w pełnym pakiecie, a skupienie uwagi na sukcesji w postaci czystej związane jest z (relatywnie) krótkim rozwojem przedsiębiorstw prywatnych w Polsce. Wykształcenie się frakcji rentierskich w strukturze klas posiadających wciąż jeszcze nie nastąpiło w Polsce w pełni.

Przywołanie konceptu struktury dziedziczenia pozwala jednak na wyjście poza perspektywę dziedziczenia majątku. Chociaż przekazanie majątku jest kluczowym czynnikiem w reprodukcji klas posiadających, to jednak wydłużenie się średniego czasu trwania życia w połączeniu z niewielkimi często inwestycjami emerytalnymi właścicieli (wielu właścicieli opłacało najniższe składki emerytalne) odsuwa ten moment w czasie. Jeśli więc w miejsce perspektywy zdarzeniowej oscylującej między stanami posiada/nie posiada wprowadzimy perspektywę procesualną, to możliwe będzie zestawienie w perspektywie sukcesyjnej struktury dziedziczonych kapitałów z temporalnym charakterem przekazywania firmy. Przywołanie takiej perspektywy prowadzi jednak do podania w wątpliwość sugerowanego okresu siedmioletniego jako optymalnego czasu trwania sukcesji. Jeśli bowiem uwzględnić proces reprodukcji klasowej, nie sposób rozpatrywać go w oderwaniu od reprodukcji habitusu klasowego $\mathrm{z}$ inkorporowanymi dyspozycjami do podejmowania określonego ryzyka, polegania na swoich umiejętnościach czy poczuciu niezależności. Innymi słowy, proces sukcesji zaczyna się dużo wcześniej, niż zakładają to podręczniki, i trwa dużo dłużej niż podpisanie dokumentów potwierdzających przekazanie firmy. Znacznie bardziej zasadne jest stwierdzenie, że w firmach rodzinnych sukcesja stale zachodzi, gdyż kiedy kończy się jedna, kolejne pokolenie już kształtuje swoje dyspozycje. Warto jeszcze dodać, że udana sukcesja nie jest jedyną drogą reprodukcji pozycji społecznej, ponieważ najbardziej oczywistą alternatywą jest założenie przez przedstawicieli młodszego pokolenia własnych firm.

Tradycyjne podejścia do sukcesji w teorii zarządzania przedsiębiorstw rodzinnych proponują transfer na podstawie tzW. modelu 3W (Budziak, 2012). Faktycznie, w większości udanych sukcesji dochodzi do takiego transferu w tej lub zbliżonej kolejności. Można jednak opisać ten transfer zasobami kapitałów niezbędnych w prowadzeniu przedsiębiorstwa, a więc w kontekście struktury dziedziczenia kapitałów.

Wiedza - to kapitał kulturowy wcielony. Często przygotowanie do sukcesji oznacza również zdobycie odpowiednich zasobów kapitału kulturowego zinstytu- 
cjonalizowanego (odpowiednie studia, certyfikaty). Dominującym zasobem jest jednak odpowiednia wiedza na temat zasad funkcjonowania przedsiębiorstwa, np. procesu produkcyjnego, rynków zbytu, sytuacji w branży czy umiejętności zarządzania finansami przedsiębiorstwa. Transfer wiedzy dokonuje się w procesach zarówno uświadomionych, jak i nieuświadomionych, przy czym wcześniejsze są te nieuświadomione: rozmowy o firmie w domu trwają często bez przerwy, firma nieraz jest placem zabaw z dzieciństwa oraz obszarem pierwszego zarobkowania. Uświadomiony przekaz odbywa się najczęściej już z intencją sukcesyjną i jest początkiem tegoż procesu (często jeszcze wtedy, kiedy sukcesor sam o tym nie wie).

Władza - wiązana powinna być z kapitałem społecznym, ale w części także $\mathrm{z}$ kapitałem kulturowym (zarządzanie pracownikami i procesami to też pewna umiejętność). Choć mowa o władzy sugeruje relację pionową, to praktyka firm rodzinnych pokazuje dobitnie, że podporząakowanie pracowników (często starszych i dłużej związanych z firmą niż sukcesor) nie jest oczywiste. Każda osoba kierująca firmą musi polegać na grupie osób, które będą wobec niej lojalne. Proces sukcesji jest więc także procesem przebudowy nieformalnej struktury społecznej firmy, gdyż część pracowników do końca pozostaje lojalna dawnemu szefowi, nie zawsze akceptując zmiany i wizję sukcesora. Taki okres częściowej autonomii sukcesora (np. kierowanie pewnym działem lub procesem) pozwala mu stworzyć własne zaplecze, na którym bazuje w późniejszym okresie zarządzania przedsiębiorstwem, oraz zdobyć potrzebne doświadczenie. Błędy popełnione na niższym szczeblu łatwiej bowiem usunąć, a bez ich popełnienia trudno nabyć niezbędne kompetencje.

Własność - jest istotą pola ekonomicznego. To wokół niej tworzą się największe napięcia w rodzinie biznesowej, to ona wyznacza pozycję społeczną i pozycję w rodzinie biznesowej. Przekazanie firmy to w ostatecznym rachunku przekazanie własności, jednak w istocie często następuje w pełni dopiero po śmierci nestora (częściowe przekazanie udziałów dokonuje się zwykle dużo wcześniej).

Kierunek transferu odbywa się więc od tego typu kapitału, który jest najmniej liczącym się i występującym w najmniejszym nasileniu w polu produkcji ekonomicznej (kulturowy), do tego, który jest ceniony najbardziej (ekonomiczny). Opór nestora związany z transferem poszczególnych typów kapitału jest odwrotnie symetryczny do jego znaczenia, tj. rośnie wraz z przesuwaniem się wzdłuż tego klina: nestorzy chętnie dzielą się wiedzą z młodszym pokoleniem, zainteresowanie firmą czy branżą przejawiane przez potencjalnych sukcesorów witają z przyjemnością, a często wręcz zachęcają dzieci do poznania firmy rodzinnej. Dużo trudniej rozstać się z władzą w firmie. Jest to zresztą często pierwszy punkt zapalny w procesie sukcesyjnym, gdyż z perspektywy nestora przekazywanie władzy następuje zbyt szybko, a z perspektywy sukcesora - zbyt wolno. Co więcej, im większy zakres tej władzy ma zostać przekazany sukcesorom, tym trudniej nestorom podjąć taką decyzję. Dlatego też przypadki opóźniania sukcesji nazywane są syndromem księcia Karola. Zbyt szybkie jak i zbyt późne oddanie władzy w firmie jest jednak dla niej szkodliwe, gdyż w pierwszym przypadku sukcesor może nie być wystarczająco przygotowany do podjęcia takiej odpowiedzialności 48 i nie mieć odpowiedniego doświadczenia oraz szacunku pracowników firmy, 
by móc skutecznie zarządzać. Zbyt późne oddanie władzy w firmie również podważa pozycję sukcesora, który zbyt długo występuje w firmie jako wciąż niegotowy do przejęcia pełnej odpowiedzialności.

Ostatnią częścią jest transfer własności, stanowi ona bowiem zwykle część emerytury nestora, który chciałby żyć na dotychczasowym poziomie i jednocześnie uwolnić się od brzemienia obowiązku. Oznacza to jakiś poziom własności w firmie. W Polsce wciąż rzadkością jest nałożenie na sukcesora z rodziny obowiązku spłaty wobec nestora (kłóci się to z wyznawanymi wartościami rodzinnymi). Stanowi to jednak podwójne wyzwanie, gdyż firma musi zapewnić odpowiednie źródło dochodów powiększonej liczbie beneficjentów, a jednocześnie sam proces sukcesyjny obciąża zasoby firmy.

\section{Sukcesja jako trajektoria rekonfiguracji kapitałów klas posiadających}

Przechodząc od analizy struktury dziedziczenia do modalnych trajektorii sukcesyjnych, trzeba pamiętać, że sukcesja nie jest jedyną ścieżką, w ramach której może dojść do reprodukcji pozycji klasowych. Ponadto należy też wziąć pod uwagę fakt, że wielu potencjalnych sukcesorów zamiast reprodukcji pozycji pragnie realizować trajektorię wznoszącą, na co nie pozwala potencjał firmy. Potencjał sukcesyjny polskich przedsiębiorstw nie jest bardzo duży, gdyż wiele z nich stanowią firmy zbyt małe i generujące zbyt niskie dochody, by utrzymać dwie rodziny. Dotyczy to głównie przedsiębiorstw mikro, które stanowią aż $96 \%$ wszystkich zarejestrowanych firm, i pewnego, trudnego do oszacowania, odsetka firm małych. „Można więc wnioskować, że prawdopodobieństwo znalezienia $\mathrm{w}$ rodzinach przedsiębiorców chętnego sukcesora będzie trudne" (Safin, Pluta, Pabjan, 2014, s. 53). Tym samym może pojawić się na rynku kategoria firm osieroconych, które nie znajdą swoich sukcesorów. Ewentualne sukcesje w tym obszarze wiązać się mogą ze względnym niepowodzeniem realizacji alternatywnych ścieżek zawodowych, a w szczególności z niepowodzeniami w realizowaniu trajektorii wznoszących.

Tak niewielki potencjał sukcesyjny znajduje odzwierciedlenie w niedużym zainteresowaniu potencjalnych sukcesorów. Badania prowadzone wśród potencjalnych sukcesorów wskazują, że zaledwie $6,3 \%$ dzieci z rodzin biznesowych zainteresowanych jest przejęciem biznesu rodzinnego (Lewandowska, Tylczyński, 2014, s. 14). Oczywiście wyniki te uzupełniają się wzajemnie, gdyż niewielkiemu potencjałowi sukcesyjnemu towarzyszy niewielka gotowość do sukcesji. Czy w takim razie nie mamy do czynienia z sytuacją, którą kolokwialnie można nazwać „wiele hałasu o nic"? Niezupełnie. Pomijając potencjalne niedoszacowanie gotowości ewentualnych sukcesorów do przejęcia biznesów rodzinnych spowodowane stosunkowo młodym wiekiem badanych, nie można zakładać, że frakcje klasowe właścicieli przedsiębiorstw małych i dużych zostaną zreprodukowane w pełni. 
Doświadczenia innych państw, w których ciągłość sukcesyjna nie została przerwana, wskazują, że zaledwie $18 \%$ firm rodzinnych zostaje przekazanych sukcesorom i pozostaje $\mathrm{w}$ zarządzie rodziny. Tak więc degradacja dolnych segmentów frakcji posiadających, które oscylują na pograniczu klasy robotniczej i właścicielskiej, prowadzić może do naturalnego zmniejszania się ich liczebności wraz ze stabilizowaniem się i konsolidowaniem rynków. Los taki obserwować można było w przypadku powolnej degradacji targowisk nieradzących sobie z konkurencją ze strony dyskontów i dotyka dziś wielu branż drobnego rzemiosła.

Maria Adamska zwraca uwagę na nieatrakcyjność dla młodszej generacji stylu życia pokolenia nestorów (Adamska, 2014, s. 16). Dorastając we względnym dostatku dostrzegają przede wszystkim wady prowadzenia własnej działalności, a w szczególności podporządkowanie życia osobistego i rodzinnego firmie. To ogólny brak zbalansowania życia i pracy może być czynnikiem odstraszającym od przejęcia firmy rodzinnej. Brak zainteresowania sukcesją może też tłumaczyć chęć realizowania trajektorii wznoszących poza firmą. Paradoksalne jest bowiem to, że dobre przygotowanie do sukcesji może ją utrudnić. Jest to pułapka szczególnie istotna w przypadku niedużych firm o lokalnym zasięgu rynkowym, których właścicieli zaliczyć można do klasy średniej. Przygotowywanie sukcesorów przez wspieranie gromadzenia przez nich odpowiednich zasobów kapitału kulturowego (zwłaszcza zinstytucjonalizowanego) może prowadzić do sytuacji, w której zasoby te będą na tyle duże, a aspiracje rozbudzone, że potencjalny sukcesor wybierze inną ścieżkę kariery, np. absolwent SGH po stażu w korporacji niekoniecznie będzie zainteresowany powrotem do prowadzenia niewielkiego przedsiębiorstwa rodzinnego w małym miasteczku. W takich przypadkach dokonuje się rekonwersja kapitału ekonomicznego w kulturowy i w ostatecznym rachunku opuszczenie frakcji posiadających klas średnich. Tym samym awans społeczny realizowany jest poza klasą posiadającą.

Wyjście z grupy właścicieli, atrakcyjne dla pochodzących z niższych warstw klasy średniej, nie jest już tak atrakcyjne w przypadku sukcesorów z klasy wyższej i wyższych warstw klasy średniej. W takim przypadku dziedziczenie pozycji bywa bardziej prawdopodobne, gdyż potencjał sukcesyjny jest wyższy. Wobec braku odpowiednich badań nie sposób odpowiedzieć na pytanie, czy gotowość do przejęcia firmy jest wyższa, kiedy firma jest większa. Na razie bowiem nie próbowano ustalić takiej korelacji między potencjałem sukcesyjnym a gotowością sukcesyjną młodszej generacji. Dobrze funkcjonujące przedsiębiorstwo rodzinne stanowi jednak dogodną bazę potencjalnego awansu społecznego. Na spotkaniach firm rodzinnych, a także w wywiadach ${ }^{5}$ sukcesorzy wskazywali, że początkowo wcale nie zamierzali pracować w firmie rodzinnej ani jej przejmować, jednak z czasem dochodzili do wniosku, że może nie uda im się zbudować podobnych firm w ciągu życia i wolą bazować na już zapoczątkowanym przedsięwzięciu (próg wejścia w pole produkcji ekonomicznej znajduje się dziś znacznie wyżej, niż był na początku lat 90.). Ponadto powroty do firm rodzinnych (porzucenie ścieżek korporacyjnych) wiązały się też z realną oceną

${ }^{5}$ Badania autora są w toku, wobec czego nie stanowią podstawy dla niniejszego artykułu. Przywoływane wnioski powstały na podstawie wstępnego podsumowania zakończonej części badań. 
szans i decyzją o alokacji kapitałów. Dostrzegając swoje deficyty kapitałów (szczególnie kapitału społecznego), sukcesorzy decydowali się na powrót do firmy rodzinnej, uznając, że nie osiągną realnej poprawy swojej pozycji pozostając w korporacji. Niezależnie od tego, czy autorzy tych wypowiedzi doznali porażek w samodzielnej drodze biznesowej, czy nie, istotne są ambicje rozwinięcia i przekształcenia firm, które przejmowali. Nie zawsze branża działalności firmy macierzystej jest bowiem zgodna z zainteresowaniami sukcesora, który może wykorzystać ją jako „larwę”, na bazie której powstanie nowe przedsięwzięcie. Możliwe są liczne inne drogi, np. powstanie konsorcjum rodzinnego, w ramach którego pod firmę macierzystą podpięte są przedsięwzięcia poszczególnych sukcesorów, czy wreszcie następuje poszerzanie zakresu działalności firmy o kolejne obszary, bardziej zbieżne z intencjami sukcesora. Losy takich przedsięwzięć mogą być różne: zarówno przyczyniać się do rozkwitu firmy i podniesienia jej na poziom niemożliwy do zrealizowania dotychczasową ścieżką biznesową, jak i do degradacji firmy macierzystej, wykrwawionej finansowaniem pobocznych działalności i zaniedbanej inwestycyjnie. Tak czy inaczej wachlarz dostępnych rozwiązań (oraz nieznanych dziś jeszcze rozstrzygnięć gry w polu biznesowym) jest dość szeroki, jednak wspólne dla wszystkich tych ścieżek jest kluczowe znaczenie rekonwersji zgromadzonego kapitału ekonomicznego ${ }^{6}$. To skoncentrowanie na kapitale ekonomicznym widoczne jest też w chęci zabezpieczenia finansowego tych spadkobierców, którzy nie przejmą firmy (np. spłacenie przez sukcesora pozostałego rodzeństwa bądź przekazanie innych form kapitału ekonomicznego przez nestorów).

Oprócz wspomnianych trajektorii opuszczenia frakcji posiadających (preferowana droga to kariera w korporacji, a więc trajektoria przejścia ze starych do nowych klas średnich) oraz reprodukcji pozycji wskutek przejęcia firmy rodzinnej (sukcesja w firmie), trzecią potencjalnie wybieraną możliwością jest prowadzenie przez przedstawicieli młodego pokolenia własnego biznesu (Lew andow ska $\mathrm{i}$ in., 2015). Oczywiście możliwe są strategie mieszane (np. łączenia własnej, niezależnej działalności z pracą w firmie rodzinnej, dopóki nowe przedsięwzięcie nie stanie się dochodowe), niemniej chęć powtórzenia ścieżki rodziców (abstrahując od tego, czy dokonanej na bazie kapitału rodziny biznesowej, czy nie) wskazuje na wykształcenie się pewnego habitusu klas posiadających. Kwestia ta jest szczególnie istotna w kontekście odtwarzania się klasy przedsiębiorców, gdyż dla dzisiejszego pokolenia nestorów habitus klasy posiadającej jest habitusem wtórnym, podczas gdy dla pokolenia sukcesorów jest habitusem pierwotnym, rodzinnym. Zarówno w opracowaniach o charakterze poradnikowym, jak i w opracowaniach badawczych powraca kwestia wartości jako kluczowego elementu powodzenia całego procesu (Safin, Pluta, Pabjan, 2014, s. 48-49). Jednocześnie niedostrzegane jest znaczenie wykształcających się dyspozycji typowych dla przedsiębiorców (np. utożsamiania sukcesu firmy z sukcesem osobistym). Owe inkorporowane wartości i dyspozycje mogą tłumaczyć chęć pracy na swoim, bycia szefem dla

${ }^{6}$ Zgłaszane niekiedy głosy krytyki ograniczenia sukcesji do kwestii firmy odnoszą się właśnie do tego, że problemem jest cały majątek rodziny biznesowej, a nie wyłącznie firma. 
samego siebie czy w końcu mierzenia własnej wartości swoim sukcesem biznesowym. W modnym dziś ruchu start-upów daje to aktorom wywodzącym się ze środowisk przedsiębiorców rodzinnych istotną przewagę w postaci odpowiednich kompetencji, nawyków i znajomości zasad prowadzenia biznesu. Choć więc przypadki zakładania samodzielnie działalności biznesowej nie stanowią klasycznego przykładu rekonwersji, w której to struktura kapitału premiuje jego formę ekonomiczną, to nadal można uznawać je za przykłady reprodukcji pozycji. Jest to więc sukcesja roli, choć poza firmą rodzinną.

Wszystkie te procesy rekonwersji odbywają się w określonym polu. W gospodarce kapitalistycznej tym polem jest rynek, na którym aktorzy funkcjonują i który jest wypadkową ich działań: zwycięstw i porażek. Obserwowanie procesów sukcesyjnych $\mathrm{w}$ wąskim sensie, a reprodukcyjnych w szerokim - ma znaczenie dla przekształceń owego pola, przy czym procesy te są przez zmiany rynku i otoczenia rynkowego jednocześnie moderowane. Warto więc na chwilę spojrzeć z perspektywy rynkowej na toczące się procesy sukcesyjne. Przede wszystkim skumulowanie tych procesów wynika $\mathrm{z}$ interwałowego charakteru owych przekształceń. Przełom lat 80 . i 90. XX wieku to moment założycielski, a 25 lat później następuje fala sukcesyjna. Już widać, że procesy te są długotrwałe, więc za kolejne 25 lat grzbiet tej fali będzie dużo bardziej spłaszczony, a sukcesje rozciągnięte w czasie. Ponadto, miejmy nadzieję, świadomość znaczenia sukcesji będzie znacznie wyższa. W chwili obecnej warto podkreślić nakładanie się procesów konsolidacji na rynkach z procesami sukcesyjnymi. Oczywiście poszczególne branże rządzą się własnymi prawami, jednak w części z nich okres konsolidacji właśnie nadszedł lub nadal trwa. Nie wszystkim firmom powiedzie się proces sukcesji. Oczyści to zapewne rynek i zmieni zasady gry. Dla wielu rodzin biznesowych sprzedaż firmy może stać się jedynym sensownym rozwiązaniem, co pozwoli innym firmom rodzinnym na powiększenie lub poszerzenie skali ich działalności. Warto obserwować te przemiany, w nich bowiem wykuwa się nowy ład gospodarczy i kształt kapitalizmu w Polsce. Dzisiejsi sukcesorzy będą kształtować to pole przez kolejne kilka dziesięcioleci, gdyż nie tylko pole tworzy habitus, ale jest też jednocześnie przez habitus tworzone.

\section{Bibliografia}

Adamska M., 2014: Praktyka sukcesji w Polsce. W: M. Adamska, A. Bocheński, E. Iskierka-Kasperek, R. Kołodziej, A. Marjański, P. Rataj, M. Tiahnybok, 2014: Przewodnik po sukcesji w firmach rodzinnych. Kompendium wiedzy. Kraków: PM Doradztwo Gospodarcze.

Adamska M., Bocheński A., Iskierka-Kasperek E., Kołodziej R., Marjański A., Rataj P., Tiahnybok M., 2014: Przewodnik po sukcesji w firmach rodzinnych. Kompendium wiedzy. Kraków: PM Doradztwo Gospodarcze.

Bourdieu P., 1985: The Social Space and the Genesis of Groups. „Theory and Society”, Vol. 14, Nr 6, s. $723-744$. 
Bourdieu P., 2005: Dystynkcja. Społeczna krytyka władzy sadzenia. Przeł. P. Biłos. Warszawa: Scholar.

Bourdieu P., 2008: Zmyst praktyczny. Przeł. M. Falski. Kraków: Wydawnictwo Uniwersytetu Jagiellońskiego.

Bucholc M., 2012: Konserwatywna utopia kapitalizmu. Etyczne iluzje międzywojennego kupiectwa. Warszawa: Wydawnictwo Naukowe PWN.

Budziak T., 2012: Sukcesja $w$ rodzinie biznesowej. Spojrzenie praktyczne. Warszawa: Poltext.

Budziak T., 2014: Esencja sukcesji. Gliwice: Helion.

Domański H., 2015: Czy w Polsce sa klasy społeczne? Warszawa: Wydawnictwo Krytyki Politycznej.

Eyal G., Szelenyi I., Townsley E.R., 1998: Making Capitalism without Capitalists. Class Formation and Elite Struggles in Post-Communist Central Europe. LondonNew York: Verso.

Gardawski J., 2013: Społeczna genealogia klasy przedsiębiorców prywatnych w III Rzeczpospolitej. W: J. Gardawski, red.: Rzemieślnicy i biznesmeni. Właściciele matych i średnich przedsiębiorstw prywatnych. Warszawa: Scholar.

Jacyno M., 1997: Iluzje codzienności. O teorii socjologicznej Pierre'a Bourdieu. Warszawa: Wydawnictwo IFiS PAN.

Lewandowska A., 2015: Kody wartości, czyli jak skutecznie przejść sukcesję w firmie rodzinnej. Poznań: Lewandowska i Partnerzy.

Lewandowska A., Lipiec J., 2015: Konstytucje firm rodzinnych. W kierunku dtugowieczności. Warszawa: Wolters Kluwer.

Lewandowska A., Safin K., Pluta J., Widz M., Hadryś-Nowak A., Jączyńska M., 2015: Diagnoza sytuacji sukcesyjnej $w$ przedsiębiorstwach rodzinnych w Polsce. Poznań: Instytut Biznesu Rodzinnego.

Lewandowska A., Tylczyński Ł., 2015: Kluczowe wyzwania sukcesyjne $w$ polskich firmach rodzinnych na podstawie: "Global University Entrepreneurial Spirit Students' Survey” oraz „Diagnozy sytuacji sukcesyjnej w przedsiębiorstwach rodzinnych w Polsce”. „Przedsiębiorczość i Zarządzanie”, T. 16, z. 7, s. 105-121.

Mills Ch.W., 1965: Białe kotnierzyki. Amerykańskie klasy średnie. Przeł. P. Graff. Warszawa: Książka i Wiedza.

Oss owski S., 1968: Dzieła. T. 5. Warszawa: PWN.

Safin K., 2007: Przedsiębiorstwo rodzinne. Istota i zachowania strategiczne. Wrocław: Wydawnictwo Akademii Ekonomicznej we Wrocławiu.

Safin K., Pluta J., Pabjan B., 2014: Strategie sukcesyjne polskich przedsiębiorstw rodzinnych. Warszawa: Difin.

Staniszkis J., 1990: Political Capitalism in Poland. "East European Politics and Societies", Nr 5.

Szlendak T., 2010: Socjologia rodziny. Ewolucja, historia, zróżnicowanie. Warszawa: Wydawnictwo Naukowe PWN.

Wasilewski J., 1995: Formowanie się nowej elity. Jak wiele nomenklatury zostato? W: A. Sułek, J. Styk, red.: Ludzie i instytucje. Stawanie się ładu społecznego. Lublin: Wydawnictwo UMCS.

Zarycki T., 2009: The Power of Intelligentsia: The Rywin Affair and the challenge of applying the concept of cultural capital to analyze Poland's elites. "Theory and Society", Vol. 38, Nr 6, s. 613-648. 